\title{
SELECTION OF SPECIFIC SINGLE CHAIN VARIABLE FRAGMENTS (SCFV) AGAINST POLYMYXA BETAE FROM PHAGE DISPLAY LIBRARIES
}

\author{
Mohammad Reza Safarnejad ${ }^{1,2 *}$, Hossein Safarpour ${ }^{2,3}$, Fatemeh Shahryari ${ }^{2,4}$, Marzieh Basirat ${ }^{2}$, \\ Meisam Tabatabaei ${ }^{2}$, Alaeddin Kordenaeej ${ }^{3}$, Amir Mohammad Naji , Mojdeh Kakouienejad ${ }^{5}$
}

\footnotetext{
${ }^{1}$ Department of Plant Viruses, Iranian Research Institute of Plant Protection, P.O. Box 1452-19395, Tehran, Iran

${ }^{2}$ Nanosystems Research Team (NRT), Department of Microbial Biotechnology and Biosafety, Agricultural Biotechnology Research Institute of Iran (ABRII), P.O. Box 31535-1897, Karaj, Iran

${ }^{3}$ Department of Agricultural Biotechnology, Shahed University, P.O. Box 18155-159, Tehran, Iran

${ }^{4}$ Department of Plant Pathology, Tarbiat Modares University, P.O. Box 336-14115, Tehran, Iran

${ }^{5}$ Department of Plant Pathology, Sugarebeet Seed Research Institute, P.O. Box 4114-31585, Karaj, Iran
}

Received: September 3, 2012

Accepted: October 4, 2013

\begin{abstract}
Sugar beet is one of the most important industrial crops in Iran. For the last two decades it has been mainly affected by a destructive virus, beet necrotic yellow vein virus (BNYVV). The Polymyxa betae is the only natural transmitting agent of the disease among the plants. Developing accurate diagnostic methods may have a major impact on the rising of resistant germplasms. In the present study, specific monoclonal recombinant antibodies in the form of single chain variable fragments (scFv) were obtained from naïve phage display libraries. The fungus specific glutathione-S-transferase (GST) protein was chosen as an antigen for developing antibodies and diagnostic purposes. To generate specific scFv, screening of Tomlinson phage display libraries was performed by applying both recombinant and native fungal GST. Using the recombinant GST in the panning process resulted in the isolation of an antibody only bound to recombinant GST but it failed to detect native GST in the infected plants. Alternatively, the process of panning was carried out by applying native fungal GST trapped to immunotubes through specific polyclonal antibody intermediate. The recent approach resulted in the selection of a specific scFv binding to native GST which was able to detect the presence of the fungi within infected plants. To the best of our knowledge, this is the first report on the generation of recombinant antibodies against Polymyxa betae, fungal vector of sugar beet rhizomania disease.
\end{abstract}

Key words: phage display, Polymyxa betae, rhizomania, single chain variable fragment (scFv), sugar beet

\section{INTRODUCTION}

Beet necrotic yellow vein virus (BNYVV) is the causal agent of sugar beet rhizomania, one of the most economically important viral diseases in the world. The plasmodiophoromycete Polymyxa betae is an obligate parasite of sugar beet roots and the vector of BNYVV (Keskin 1964). The yield losses caused by this disease have been alleviated by the development of resistant cultivars. Throughout the world, resistant cultivars are widely used (RichardMolard 2002). Specific and accurate diagnostic methods play important roles as essential tools in order to screen cultivars to attain resistance to the rhizomania virus and its vector.

To develop a serological test for any pathogenic agents, including $P$. betae, a specific immunogenic protein has to be identified. Glutathione S-transferase (GST) is a superfamily of multi-functional enzymes in charge of detoxifying endobiotic and xenobiotic compounds by conjugating glutathione (GSH) to a hydrophobic sub- strate (Öztetik 2008). More specifically, GST, a specific immunogenic protein, is a critical enzyme expressed in $P$. betaes̀ zoospores, sporangia, and resting spores. Glutathione S-transferase could be a good candidate for developing the serological base of a diagnostic technique, for the pathogen (Mutasa-Gottgens et al. 2000). It is worth noting, that GST is expressed at higher levels by P. betae during the infection process, to overcome the host plant defense mechanisms (Mutasa-Gottgens et al. 2000).

The development of specific antibodies is a prerequisite for the application of serological assays in the detection of plant pathogens. Production of monoclonal antibodies is more complicated than polyclonal but it would lead to high specificity and a more accurate analysis. Recombinant antibody technology, in combination with the phage display technology, provides an extremely useful approach for the production of target-specific monoclonal antibodies (Griffiths et al. 1994; Kirakosyan and Kaufman 2009). Thus far, highly specific antibodies 
have been developed in this way against several important plant pathogens (Griep et al. 1999; Villani et al. 2005; Jahromi et al. 2009; Safarnejad et al. 2009; Krishnaswamy et al. 2011; Hu et al. 2012).

In the present article, we describe the use of the phage display technique to raise a broad panel of GST-specific recombinant antibodies from a human combinatorial antibody library.

\section{MATERIALS AND METHODS}

\section{Large scale expression and purification of GST protein}

The pET28-GST construct containing the P. betae GST gene, previously prepared by Safarpour et al. (2012), was applied for bacterial expression of GST recombinant protein. The construct contained a $6 x H i s-t a g$ fusion to N-terminus of the GST encoding gene. Protein expression was carried out under native conditions and purification was performed by the ion-exchange metal affinity chromatography (IMAC) method using Ni-NTA agarose column according to the manufacturer's instructions (Qiagen USA). The purity and integrity of the produced recombinant protein were analyzed by SDS-PAGE electrophoresis as previously described (Ausubel et al. 1995).

\section{Panning of phage display libraries}

Tomlinson I \& J naïve scFv phage libraries were applied for selection of specific binders against GST protein of $P$. betae. Screening of the libraries was performed using recombinant and native fungal GST. In the first strategy, the panning process was carried out by immobilizing recombinant GST protein $(\sim 50-100 \mu \mathrm{g} / \mathrm{ml})$ overnight onto immunotubes (Nunc-Maxisorb), which had been washed with phosphate buffered saline (PBS), blocked with skim milk, and incubated with phage suspension $\left(\sim 10^{13} \mathrm{cfu}\right)$. Phage particles with affinity for the antigen were eluted using triethylamine, and used for infection and amplification of exponentially growing Escherichia coli TG1 cells (Stratagene). The panning was repeated three times and the total eluted phage titre was determined after each round of panning.

In the second approach, native fungal GST obtained from the infected plants was used for the selection of specific $\mathrm{ScFv}$ fragments. Total protein was extracted from the infected roots by homogenizing 1:3 (w/v) fresh tissues in an extraction buffer (PBS buffer $1 \mathrm{X}$ pH 7.5, EDTA $5 \mathrm{mM}$ and $\beta$-mercaptoethanol $5 \mathrm{mM}$ ). To remove plant debris, the slurry was then centrifuged ( $3 \mathrm{~min}$ at $10,000 \mathrm{~g}$ ). Immunotubes were coated overnight at $4^{\circ} \mathrm{C}$ with specific GST polyclonal antibody as previously prepared (Safarpour et al. 2012). The supernatant was added to tubes and incubated overnight at $4^{\circ} \mathrm{C}$. After washing three times with PBS and blocking for $2 \mathrm{~h}$ in $2 \%$ skim milk powder in PBS at $37^{\circ} \mathrm{C}$, all subsequent steps of panning were followed as mentioned for the first approach.

\section{Mini-induction of scFv}

To induce scFv production, 2xTY medium supplemented with $100 \mu \mathrm{g} / \mathrm{ml}$ ampicillin and $0.1 \%(\mathrm{w} / \mathrm{v})$ glucose (2xTYGA) was inoculated with a single recombinant colo- ny of E. coli strain HB2151 harbouring the $\mathrm{scFv}$ phagemid. This was incubated at $37^{\circ} \mathrm{C}$ until the $\mathrm{OD}_{600 \mathrm{~nm}}$ reached the range of 0.4-0.6. After the third round of panning, E. coli non-suppressor HB2151 cells were infected with $1 \mathrm{ml}$ of eluted phage supernatant and plated on 2xTY agar plates containing $1 \%(\mathrm{w} / \mathrm{v})$ glucose and $100 \mu \mathrm{g} / \mathrm{ml}$ ampicillin (2xTYGA-agar). Ninety-six colonies were randomly selected and were cultured in a microtitre plate. Mini-IPTG induction was performed at $30^{\circ} \mathrm{C}$ overnight, after the addition of isopropyl-b-D-thiogalactoside to a final concentration of $0.5 \mathrm{mM}$. The cells were isolated by centrifugation and supernatants were used for subsequent assays.

\section{Binding activity of scFv against GST protein}

The binding activity of selected clones was analyzed by Enzyme-Linked Immunosorbent Assay (ELISA). About $50 \mu \mathrm{g} / \mathrm{ml}$ recombinant GST in PBS was directly coated on high-binding microtitre plates (Maxisorp, Nunc, Denmark) followed by a blocking step using $2 \%$ $(\mathrm{w} / \mathrm{v})$ skim milk. After that, $100 \mu \mathrm{l}$ of scFv solutions were applied to the plates and incubated at $37^{\circ} \mathrm{C}$ for $2 \mathrm{~h}$. Bound scFvs were detected using anti-c-myc monoclonal antibody 9E10 followed by horseradish peroxidase conjugated to goat anti-mouse polyclonal antibodies. Colonies with high specificity were selected and subjected to further analysis.

The binding activity of the isolated $\mathrm{scFv}$ against native GST was checked by complementary ELISA. Analysis of clones obtained in the second approach was performed by initial capture of native fungal GST in micro-titer plates. The plates were initially coated with polyclonal antibodies and plant extract was loaded into wells. After this, $100 \mu \mathrm{l}$ of scFv solutions were applied to the plates and incubated at $37^{\circ} \mathrm{C}$ for $2 \mathrm{~h}$. Bound scFvs were detected using anti-c-myc monoclonal antibody $9 \mathrm{E} 10$ followed by horseradish peroxidase conjugated to goat anti-mouse polyclonal antibodies. As an alternative approach, the specificity of scFvs against native GST was analyzed by plate-trapped antigen (PTA)-ELISA as described by Mowat (1985) with some modifications. Fungal GST antigen in crude root extracts was adsorbed directly to Microtiter plate (Maxisorp, Nunc, Denmark), allowed to react with $\mathrm{scFv}$ and the antigen-antibody complex detected with anti-c-myc and subsequent goat anti-mouse antibodies. To prepare the crude extract, an infected root was ground 1:5 (w/v) in coating buffer. The plates were incubated overnight at $4^{\circ} \mathrm{C}$. After blocking with $1 \%$ skim milk in PBS for $1 \mathrm{~h}$ at $37^{\circ} \mathrm{C}$ and 3 rounds of washing with PBST, the cell culture supernatants (containing antibodies) were added (100 $\mu \mathrm{l}$ per well) and incubated for 2 $\mathrm{h}$ at $37^{\circ} \mathrm{C}$. The microtiter plate was washed with phosphate buffered saline with $0.05 \%$ Tween 20 (PBST) three times, and the anti-c-myc tag antibody (Abcam, USA) was added into each well. After washing the microtiter plate with PBST, goat anti-mouse IgG (Fc specific) conjugated with alkaline-phosphatease (AP) was added. The substrate was used to visualize the signal. The plate was analyzed by using an ELISA reader (Tecan, Austria). Positive clones shown in ELISA were further characterized by subsequent western blotting. 
Table 1. Enrichment of GST-specific scFv fragments through multiple rounds of panning of phage display libraries

\begin{tabular}{cccc}
\hline Approach & Round of panning & Input phage & Output phage \\
\hline \multirow{2}{*}{ First } & 1 & $10^{13}$ & $3.4 \times 10^{4}$ \\
& 2 & $10^{13}$ & $4.3 \times 10^{5}$ \\
& 3 & $10^{13}$ & $7.8 \times 10^{6}$ \\
\hline \multirow{2}{*}{ Second } & 1 & $10^{13}$ & $3.1 \times 10^{4}$ \\
& 2 & $10^{13}$ & $3.9 \times 10^{5}$ \\
\hline
\end{tabular}

\section{BstNI fingerprinting of individual phage clones}

The variability of positive clones derived from naïve libraries was determined by digesting the PCR-amplified $\mathrm{scFv}$ fragments from randomly selected bacterial colonies with $5 \mathrm{U}$ Bst NI for $2 \mathrm{~h}$ at $60^{\circ} \mathrm{C}$ (Hoogenboom et al. 1991; Marks et al. 1991).

\section{Blotting analysis}

In Western blotting, electrophoretically separated proteins were transferred from an sodium dodecyl sulfate polyacrylamide gel electrophoresis (SDS-PAGE) gel to nitrocellulose membrane $(0.45 \mu \mathrm{m})$. The membrane was blocked with PBS buffer containing $2 \%(\mathrm{w} / \mathrm{v})$ skim milk powder. The $\mathrm{scFv}$ proteins were detected by the anti-cmyc monoclonal antibody 9E10, followed by anti-mouse IgG, coupled to alkaline phosphatase (Sigma, USA). Blots were developed using 5-bromo-4-chloro-3-indolyl phosphate (BCIP) and nitroblue tetrazolium chloride (NBT) as substrate.

In dot-blot analysis, about $5 \mu \mathrm{l}$ of the infected or healthy sap obtained from sugar beet roots were immobilized on nitrocellulose membrane following incubation with $\mathrm{scFv}$ for $16 \mathrm{~h}$ at $4^{\circ} \mathrm{C}$. The $\mathrm{scFv}$ fragments were detected using 1:3,000 diluted anti-c-myc monoclonal antibody 9E10, followed by using a 1:5,000 diluted AP-labelled goat anti-mouse polyclonal antiserum. Binding of APconjugated secondary antibodies was revealed by adding 5-bromo-4-chloro-3-indolyl phosphate (BCIP) and nitro blue tetrazolium chloride (NBT) as substrate.

\section{RESULTS}

\section{Protein expression and purification}

To produce sufficient protein for the panning procedure and further characterization of the selected $\mathrm{scFv}$ fragments, 6xHis-tagged GST protein was expressed in E. coli. Expression and purification resulted in the production of varying amounts of fusion protein after induction with Isopropyl $\beta$-D-1-thiogalactopyranoside (IPTG). These results confirmed the high purity and integrity of GST protein. Generally, the total yield of the purified protein in the culture medium was estimated at $3.5 \mathrm{mg} / \mathrm{ml}$.

\section{Phage display scFv selection}

Three rounds of panning were performed using Tomlinson I \& J scFv libraries with approximately $10^{13} \mathrm{cfu}$ of recombinant phages per round. The specific $\mathrm{scFv}$ clones were isolated in two different ways; by applying either purified GST or infected sap. The population of the eluted phages was evaluated after every round of panning. Table 1 shows the enrichment of GST-specific scFv fragments throughout the panning processes. An increasing titer of the eluted phages in the subsequent rounds of panning, indicates that the number and the specificity of the eluted phages have climbed and that they were capable of binding strongly to the target antigen.

After the third round of panning, 96 colonies were randomly selected and their binding activity against GST was analysed by ELISA. In the first approach, by applying recombinant GST, approximately $50 \%$ of the clones selected from scFv Tomlinson I library displayed positive activity against recombinant GST protein (Fig. 1). Complementary ELISA analysis revealed that those $\mathrm{scFv}$ fragments did not react with native GST present in the infected plant crude extract (Fig. 2).

In the second strategy, native fungal GST was applied for screening of Tomlinson I library. The aim of this work was to place the main focus on isolating the scFvs which were basically against the naturally existing GST proteins and not the recombinant one. This was carried out by preliminary coating of an immunotube with anti-GST polyclonal antibody, followed by pouring the extract of the infected root into the immunotubes and an addition of the scFv phage libraries there. After the third round of panning, a specific clone binding to recombinant GST was obtained. To determine the binding activity of this scFv against native GST, complementary ELISA analysis was performed in two approaches. In the first approach, to trap the fungal GST, plates were initially coated with specific polyclonal antibodies against GST. The crude extract was then applied followed by loading $\mathrm{scFv}$ and the subsequent antibodies. No positive reactions for different clones were obtained when the first approach was applied. In the second approach, the crude extract of the infected plants was directly loaded into individual wells of the ELISA plate, followed by adding scFv and the subsequent antibodies. Finally, one clone producing a specific scFv capable of successfully binding to the native GST obtained from the infected plants, was obtained. This result also showed the high specificity of the isolated $\mathrm{scFv}$ against the recombinant GST protein (Fig. 2).

\section{Fingerprinting and sequencing analysis of scFv genes}

The $\mathrm{scFv}$ encoding region was PCR-amplified and subjected to fingerprinting analysis. The restriction enzyme analysis using the BstNI enzyme, showed a similar cutting pattern for all $\mathrm{scFv}$ fragments obtained from the 


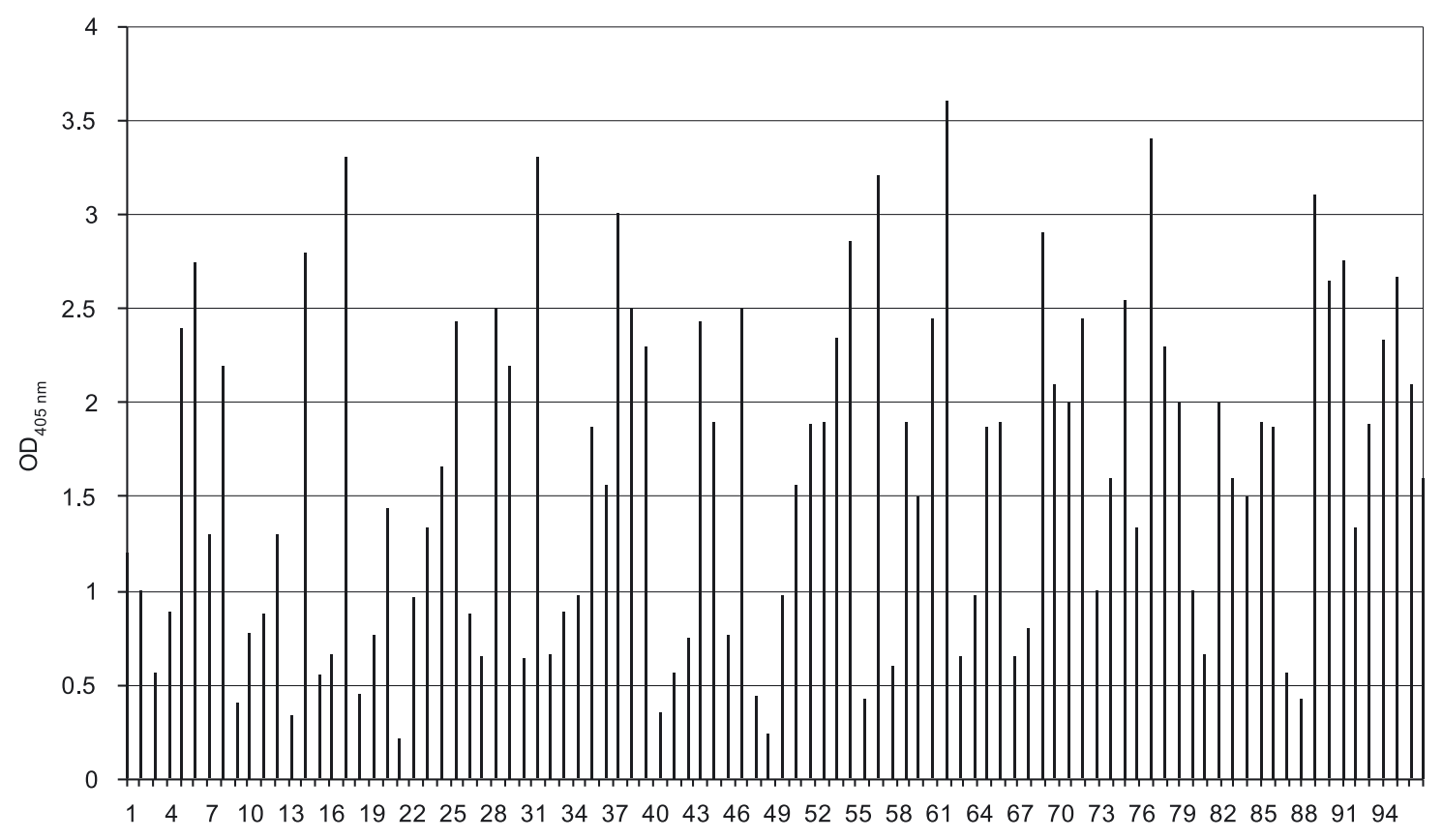

Clone number

Fig. 1. Screening of selected clones from the scFv libraries Tomlinson I in soluble ELISA. Binding activity of 96 randomly selected soluble murine scFv binding to GST protein after the third round of panning was revealed by direct ELISA. Around $50 \mu \mathrm{g} / \mathrm{ml}$ of GST was coated on microtitre plates. Bacterial supernatant was added in 2\% MPBS to a final volume of $100 \mu$. The specific scFvs were detected by adding 1:5,000 diluted 9E10 monoclonal antibody, and goat anti-mouse polyclonal antibody conjugated to horse radish peroxidase as secondary antibody $(1: 5,000)$. ELISA readings $\left(\mathrm{OD}_{405 \mathrm{~nm}}\right)$ were performed after $30 \mathrm{~min}$ of incubation with $\mathrm{ABTS}$ substrate at $37^{\circ} \mathrm{C}$

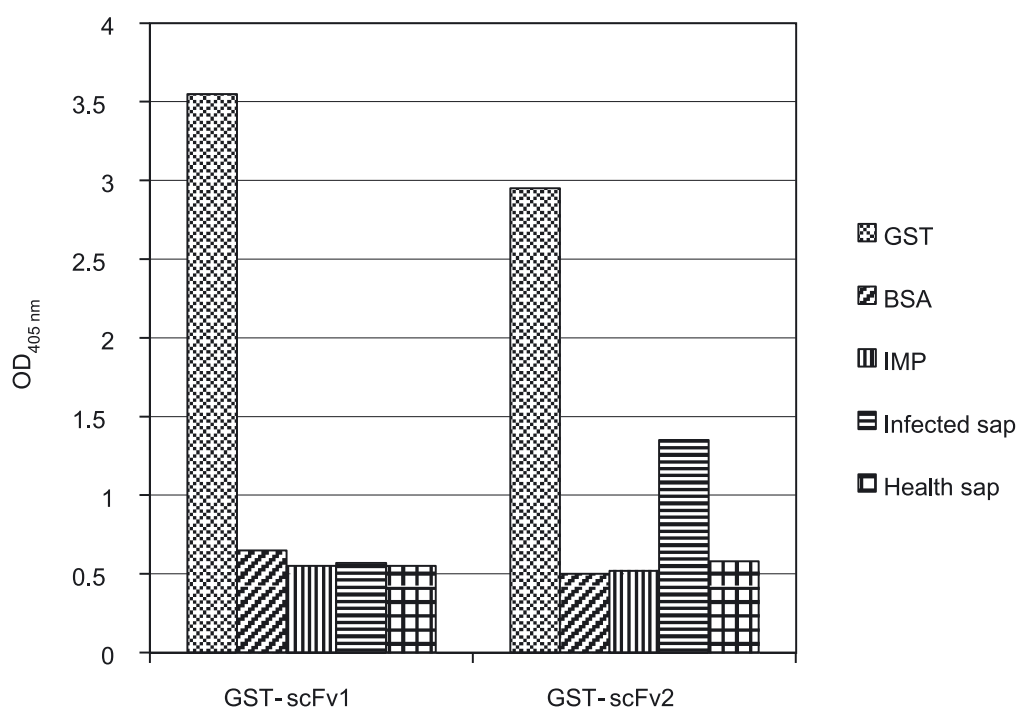

Fig. 2. ELISA results by using scFvs produced by different clones with different antigens. Bound scFvs were detected with the 9E10 monoclonal antibody and a horse radish peroxidase-conjugated goat anti-mouse polyclonal antibody. ELISA readings $\left(\mathrm{OD}_{405 \mathrm{~nm}}\right)$ were obtained after $30 \mathrm{~min}$ of incubation with $\mathrm{ABTS}$ substrate at $37^{\circ} \mathrm{C}$ 
$\begin{array}{llllllll}M & 1 & 2 & 3 & 4 & 5 & 6 & 7\end{array}$
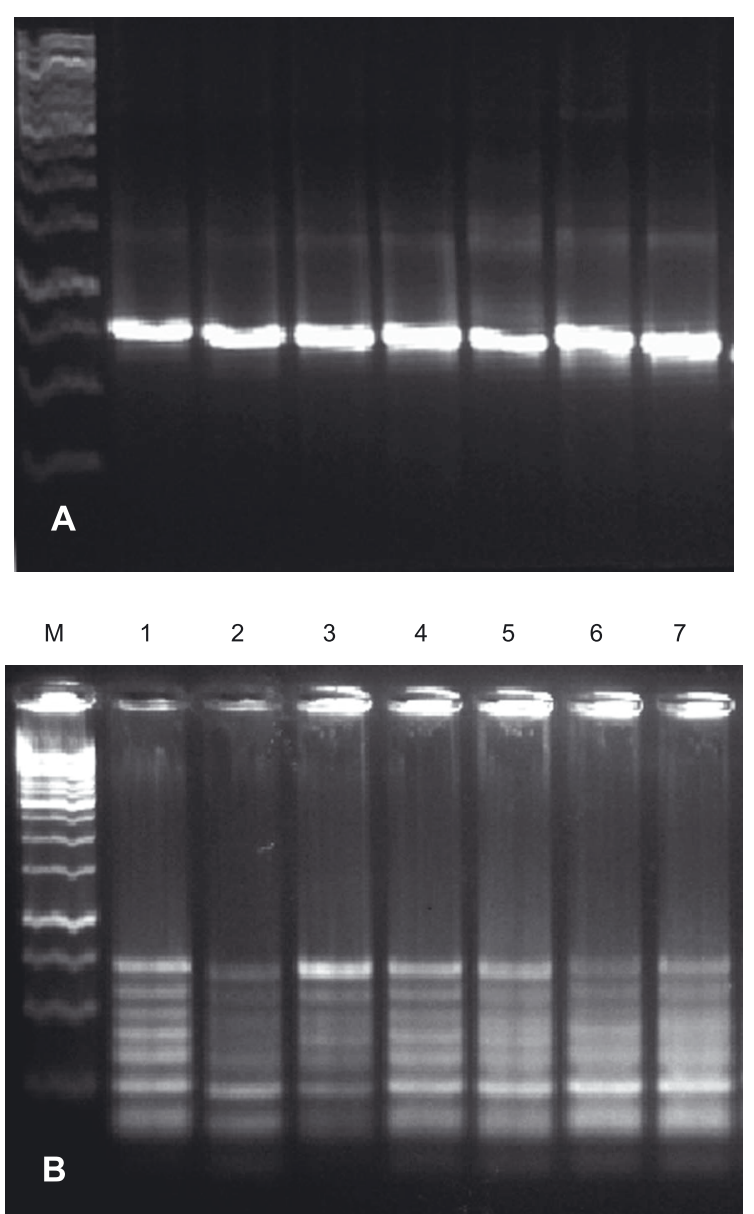

Fig. 3. Analysis of PCR product of GST binder clones from Tomlinson I phage display library (A) and subsequent finger printing analysis (B). The scFvs gene was amplified by specific $\mathrm{pHEN}$ primers and subjected to BstNI digestion. Samples were analyzed on a $1 \%(\mathrm{w} / \mathrm{v})$ agarose gel. 1 - $1 \mathrm{~Kb}$ DNA ladder; $2-8$ - patterns of 7 selected clones reacting to GST

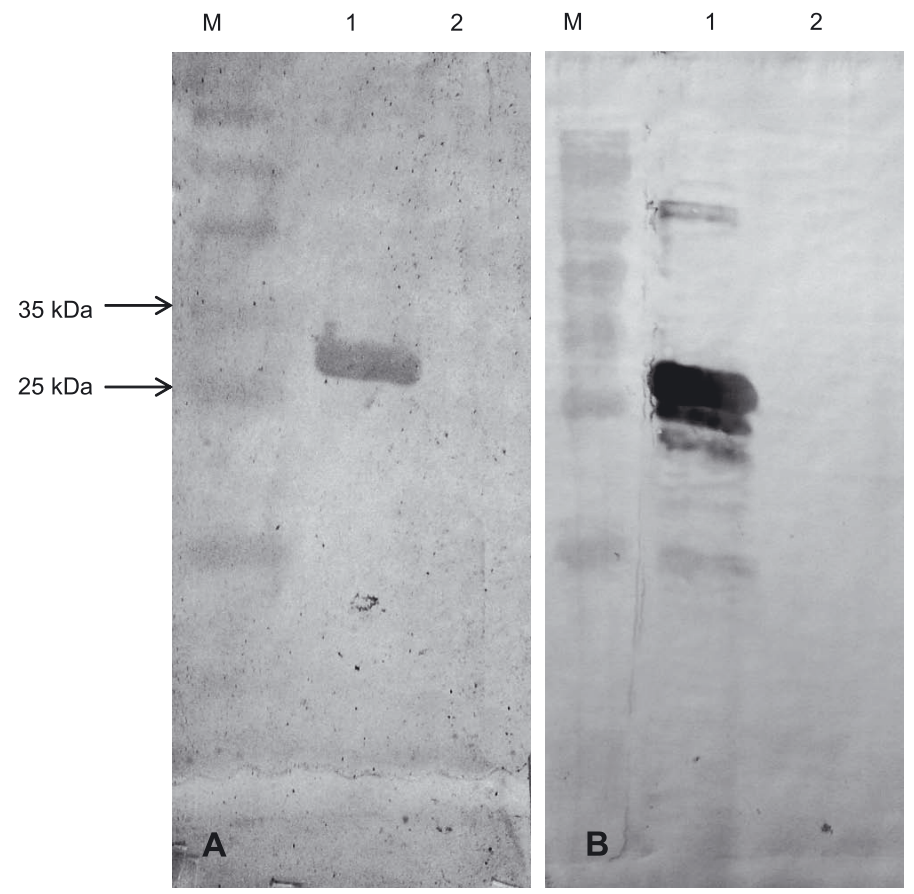

Fig. 4. Immuno-blot analysis of bacterially expressed GST-scFv1 (A) and GST-scFv2 (B). Periplasmicly expressed scFvs were separated on a $12 \%(\mathrm{w} / \mathrm{v})$ SDS-PAGE gel and blotted onto nitrocellulose membrane. The blotted scFvs were revealed by $9 \mathrm{E} 10$ monoclonal antibody and GAM ${ }^{\mathrm{AP}}$ antibody conjugated to alkaline phosphatase, followed by staining with NBT/BCIP. M - protein marker; 1 - GST; 2 - BSA (the negative control) 
positive clones selected in the first approach (Fig. 3). The plasmid DNA from these clones was isolated and used for sequencing analysis using specific primers for $\mathrm{pHEN}$ vector. The results confirmed that all the positive clones obtained in the first approach of panning contained the same sequence, named GST-scFv1 (predicted mass of 28.1 $\mathrm{kDa})$. Alignment analysis with the available sequences in the the international ImMunoGeneTics information system (IMGT) database showed that the $\mathrm{V}_{\mathrm{H}}$ and $\mathrm{V}_{\mathrm{L}}$ fragments of GST-scFv1 were members of different groups. The program BLAST was used to compare the obtained GST-scFv1 sequence with those of the National Center for Biotechnology Information (NCBI) Gene Bank, and a similarity level of approximately $96 \%$ was shown with the submitted genes encoding the antibody TREM (anti-TREM-like transcript-1 antibody, Accession No. DQ375450.1).

\section{Blotting analysis}

In the present study, all scFvs produced their relevant bands with the expected band of the protein when western blotting was conducted (Fig. 4). Complementary western blotting analysis confirmed that all scFvs were only able to react with the recombinant GST but complementary WB analysis failed to detect the infected plants. The results obtained in Dot Immuno Blott Assay (DIBA) analysis, also confirmed the specificity of the GST-scFv2 against fungal GST. Therefore, GST-scFv2 is able to separate the healthy and infected samples (results are not shown).

\section{DISCUSSION}

To generate a specific antibody against $P$. betae, a certain immunogenic protein that exists in all the morphologically different stages of the pathogen's life cycle, has to be identified. Mutasa-Göttgens et al. (2000) reported the presence of GST protein in zoospores, sporangia, and resting spores of the fungus. High levels of GST proteins in infected sugar beet root have also been identified (Mutasa-Gottgens et al. 2000). Furthermore, it is a strong immunogenic protein and therefore, could be a good candidate for identifying the fungus. In the present study, the fungal GST protein was selected as an antigen for developing recombinant antibodies and the detection of infected plants.

Expression and purification steps in our study resulted in the production of about $3.5 \mathrm{mg}$ GST protein from one liter of the culture medium. The major part of the purified proteins, however, were precipitated. To overcome this problem, some treatments such as adding imidazole (Safarnejad et al. 2008) and reducing the total concentration (Treuheit et al. 2001) were performed. According to the results, the second approach had a major effect on reducing the precipitation in test tubes. The positive effect of concentration reduction on preventing protein sedimentation has been reported in previous studies as well (Treuheit et al. 2001).

Obtaining specific monoclonal antibodies by traditional methods such as hybridoma technology, requires expensive specialized facilities for animal tissue culturing and is time consuming. In the present study and for the first time, phage display technology has been applied for the generating specific monoclonal recombinant antibodies against $P$. betae. This technology has been exploited widely for generation of specific antibodies against several plant disease agents including viruses (Fischer et al. 2001; Schillberg et al. 2001; Prins et al. 2005; Safarnejad et al. 2009; Cervera et al. 2010) and plant pathogenic fungi such as Fusarium oxysporum (Peschen et al. 2004; Li et al. 2008) and Sclerotinia sclerotiorum (Yajima et al. 2008). The main advantage of this technology is that there is no need for an equipped laboratory. This means that major concerns about the ethical issues of using animals for immunization can be bypassed. The antibody genes obtained in this approach could be applied for developing resistance against plant pathogens of concern (Safarnejad et al. 2011). Specific antibodies against any type of antigens could be obtained within a month (Rodi et al. 2001).

In the present study, two recombinant antibodies were generated, named as GST-scFv1 and GST-scFv2. Both showed strong binding activities against the recombinant GST. The first one, GST-scFv1, only showed a high specificity against recombinant GST but did not detect the native GST present in the infected plants. This could be ascribed to the existing differences in the three dimensional (3D) structure of the folded recombinant and native proteins. Similar findings have been reported in a previous study (Liu et al. 1999). To overcome this challenge, a system was designed to obtain specific antibodies against native GST protein present in the infected plants. To achieve this goal, the native GST present in the plant extract was captured in pre-bound tubes with polyclonal antibodies against GST. Finally, by applying this system, a specific $\mathrm{scFv}$ with binding activities against both recombinant and native GST protein was obtained. Further immunoassay analysis proved that this $\mathrm{scFv}$ is able to detect the presence of the P. betae within infected plants. A similar approach has been previously investigated for the generation of specific scFv against tospoviruses (Franconi et al. 1999).

The bacteria clones containing the recombinant antibody genes can be used as a valuable source for mass production of recombinant antibodies for diagnostic purposes, such as development of serological or nano-based biosensors.

\section{REFERENCES}

Ausubel F.M., Brent R., Kingston R.E., Moore D.D., Seidman J.G., Smith J.A., Struhl K. (eds.). 1995. Current Protocols in Molecular Biology. John Wiley \& Sons, Hoboken, NJ: 3.1.1-3.1.21.

Cervera M., Esteban O., Gil M., Gorris M.T., Martínez M.C., Peña L. 2010. Transgenic expression in citrus of single-chain antibody fragments specific to Citrus tristeza virus confers virus resistance. Transgenic Res. 19 (6): 1001-1015.

Fischer R., Emans N., Schillberg S. 2001. Achieving plant disease resistance by antibody expression. Can. J. Plant Pathol. 23 (3): 236-245.

Franconi R., Roggero P., Pirazzi P., Arias F.J., Desiderio A., Bitti O., Pashkoulov D., Mattei B., Bracci L., Masenga V., Milne 
R.G., Benvenuto E. 1999. Functional expression in bacteria and plants of an scFv antibody fragment against tospoviruses. Immunotechnology 4 (3-4): 189-201.

Griep R.A., Van Twisk C., Schots A. 1999. Selection of Beet necrotic yellow vein virus-specific monoclonal antibodies from a semisynthetic combinatorial antibody library. Eur. J. Plant. Pathol. 105 (2): 147-156.

Griffiths A.D., Williams S.C., Hartley O., Tomlinson I.M., Waterhouse P., Crosby W.L., Kontermann R.E., Jones P.T., Low N.M., Allison T.J., Prospero T.D., Hoogenboom H.R., Nissim A., Cox J.P.L., Harrison J.L., Zaccolo M., Gherardi E., Winter G. 1994. Isolation of high affinity antibodies directly from large synthetic repertoires. EMBO J. 13 (14): 3245-3260.

Hoogenboom H.R., Griffiths A.D., Johnson K.S., Chiswell D.J., Hudson P., Winter G. 1991. Multi-subunit proteins on the surface of filamentous phage: Methodologies for displaying antibody (Fab) heavy and light chains. Nucleic Acids Res. 19 (15): 4133-4137.

Hu Z.Q., Liu J.L., Li H.P., Xing S., Xue S., Zhang J.B., Wang J.H., Nölke G., Liao Y.C. 2012. Generation of a highly reactive chicken-derived single-chain variable fragment against $\mathrm{Fu}$ sarium verticillioides by phage display. Int. J. Mol. Sci. 13 (6): 7038-7056.

Jahromi Z.M., Salmanian A.H., Rastgoo N., Arbabi M. 2009. Isolation of BNYVV coat protein specific single chain Fv from a mouse phage library antibody. Hybridoma (Larchmt) 28 (5): 305-313.

Keskin B. 1964. Polymyxa betae n. sp., ein parasit in den Wurzeln von Beta vulgaris Tournefort, besonders während der Jugendentwicklung der Zuckerrübe. Arch. Mikrobiol. 49 (4): 348-374.

Kirakosyan A., Kaufman P.B. 2009. Recent advances in plant biotechnology. p. 35-63. In "Molecular Farming of Antibodies in Plants" (R. Fischer, S. Schillberg, R.M. Twyman, eds.). Springer, USA, $428 \mathrm{pp}$.

Krishnaswamy S., Kabir M.E., Rahman M.M., Miyamoto M., Furuichi Y., Komiyama T. 2011. Isolation and characterization of recombinant single chain fragment variable anti-idiotypic antibody specific to Aspergillus fumigates membrane protein. J. Immunol. Methods 366 (1): 60-68.

Li H.P., Zhang J.B., Shi R.P., Huang T., Fischer R., Liao Y.C. 2008. Engineering Fusarium head blight resistance in wheat by expression of a fusion protein containing a Fusarium-specific antibody and an antifungal peptide. Mol. Plant. Microbe. In. 21: $1242-1248$.

Liu F., Sukhacheva E., Erokhina T., Schubert J. 1999. Detection of potyviral nuclear inclusion $\mathrm{b}$ proteins by monoclonal antibodies raised to synthetic peptides. Eur. J. Plant Pathol. 105 (4): 389-395.

Marks J.D., Hoogenboom H.R., Bonnert T.P., McCafferty J., Griffiths A.D., Winter G. 1991. By-passing immunization. Human antibodies from V-gene libraries displayed on phage. J. Mol. Biol. 222 (3): 581-597.

Mowat W. 1985. Simplified enzyme immunoassay for plant virus detection and identification. Report of the Scottish Crop Research Institute for 1984, 188 pp.

Mutasa-Gottgens E.S., Chwarszczynska D.M., Halsey K., Asher M.J.C. 2000. Specific Polyclonal antibodies for the obligate plant parasite Polymyxa - a targeted recombinant DNA approach. Plant Pathol. 49 (2): 276-287.

Öztetik E. 2008. A tale of plant glutathione S-transferases: since 1970. Bot. Rev. 74 (3): 419-437.

Peschen D., Li H.P., Fischer R., Kreuzaler F., Liao Y.C. 2004. Fusion proteins comprising a Fusarium-specific antibody linked to antifungal peptides protect plants against a fungal pathogen. Nat. Biotechnol. 22 (6): 732-738.

Prins M., Lohuis D., Schots A., Goldbach R. 2005. Phage displayselected single-chain antibodies confer high levels of resistance against Tomato spotted wilt virus. J. Gen. Virol. 86 (7): 2107-2113.

Richard-Molard M. 2002. Rhizomania: interactions varietes $x$ lieux et consequences. Proceedings of the 65th IIRB Congress, Brussels: 239-245.

Rodi D.J., Makowski L., Kay B.K. 2001. One from column A and two from column B: the benefits of phage display in molecular-recognition studies. Curr. Opin. Chem. Biol. J. 6 (1): 92-96.

Safarnejad M.R., Fischer R., Commandeur U. 2008. Generation and characterization of functional recombinant antibody fragments against Tomato yellow leaf curl virus replication-associated protein. Commun. Agric. Appl. Biol. Sci. 73 (2): 311-323.

Safarnejad M.R., Fischer R., Commandeur U. 2009. Recombinant-antibody-mediated resistance against Tomato yellow leaf curl virus in Nicotiana benthamiana. Arch. Virol. 154 (3): 457-467.

Safarnejad M.R., Salehi Jouzani G.R., Tabatabaie M., Twyman R.M., Schillberg S. 2011. Antibody-mediated resistance against plant pathogens. Biotechnol. Adv. 29 (6): 961-971.

Safarpour H., Safarnejad M.R., Basirat M., Hasanzadeh F., Kamyab F. 2012. Development of a specific serological kit for detection of Polymyxa betae, transmitting agent of sugar beet Rhizomania disease. J. Food Agric. Environ. 10 (3-4): 729-732.

Schillberg S., Zimmermann S., Zhang M.Y., Fischer R. 2001. Antibody-based resistance to plant pathogens. Transgenic Res. 10 (1): 1-12.

Treuheit M.J., Kosky A.A., Brems D.N. 2001. Inverse relationship of protein concentration and aggregation. Pharmaceut. Res. 19 (4): 511-516.

Villani M.E., Roggero P., Bitti O., Benvenuto E., Franconi R. 2005. Immunomodulation of cucumber mosaic virus infection by intra bodies selected in vitro from a stable single framework phage display library. Plant Mol. Biol. 58 (3): 305-16.

Yajima W., Rahman M.H., Das D., Suresh M.R., Kav N.N. 2008. Detection of Sclerotinia sclerotiorum using a monomeric and dimeric single-chain fragment variable ( $\mathrm{scFv}$ ) antibody. J. Agric. Food Chem. 56 (20): 9455-9463. 